\title{
LOAD THAT MAXIMIZES POWER OUTPUT IN COUNTERMOVEMENT JUMP
}

\author{
CARGA QUE MAXIMIZA A POTÊNCIA DE SAÍDA NO SALTO COM CONTRAMOVIMENTO
}

CARGA CON LA QUE SE ALCANZA LA MÁXIMA POTENCIA EN EL SALTO CON CONTRAMOVIMIENTO
Original Article

Artigo OrIGINAL

Artículo Original
Pedro Jimenez-Reyes ${ }^{1}$ (Educador Físico)

Victor Cuadrado-Peñafiel ${ }^{2}$ (Educador Físico)

Fernando Pareja-Blanco 3 (Educador Físico)

Juan Párraga-Montilla ${ }^{4}$ (Educador Físico)

Francisco Javier Toscano Bendala' (Educador Físico)

Juan José Gonzalez-Badillo³ (Educador Físico)

1. Universidad Católica San Antonio. Departamento de Actividad Física y Ciencias del Deporte, Guadalupe, Murcia, España.

2. Universidad Complutense de Madrid. Departamento de Expresión Corporal, Madrid, España.

3. Universidad Pablo de Olavide de Sevilla. Departamento de Deporte e Informática, Sevilla, España. 4. Universidad de Jaén,

Departamento de Expresión Corporal, Jaén, España.

\section{Correspondence:}

Facultad de Ciencias de la Actividad Física y del Deporte. Universidad Católica San Antonio de Murcia. Campus de los Jerónimos s/n. 30107. Guadalupe, Murcia, Spain. peterjr49@hotmail.com

\begin{abstract}
Introduction: One of the main problems faced by strength and conditioning coaches is the issue of how to objectively quantify and monitor the actual training load undertaken by athletes in order to maximize performance. It is well known that performance of explosive sports activities is largely determined by mechanical power. Objective: This study analysed the height at which maximal power output is generated and the corresponding load with which is achieved in a group of male-trained track and field athletes in the test of countermovement jump (CMJ) with extra loads $\left(\mathrm{CMJ}_{\mathrm{EL}}\right)$. Methods: Fifty national level male athletes in sprinting and jumping performed a CMJ test with increasing loads up to a height of $16 \mathrm{~cm}$. The relative load that maximized the mechanical power output $\left(P_{\max }\right)$ was determined using a force platform and lineal encoder synchronization and estimating the power by peak power, average power and flight time in CMJ. Results: The load at which the power output no longer existed was at a height of $19.9 \pm 2.35$, referring to a $99.1 \pm 1 \%$ of the maximum power output. The load that maximizes power output in all cases has been the load with which an athlete jump a height of approximately $20 \mathrm{~cm}$. Conclusion: These results highlight the importance of considering the height achieved in CMJ with extra load instead of power because maximum power is always attained with the same height. We advise for the preferential use of the height achieved in $\mathrm{CMJ}_{\mathrm{EL}}$ test, since it seems to be a valid indicative of an individual's actual neuromuscular potential providing a valid information for coaches and trainers when assessing the performance status of our athletes and to quantify and monitor training loads, measuring only the height of the jump in the exercise of $\mathrm{CMJ}_{\mathrm{El}}$.
\end{abstract}

Keywords: athletic performance; track and field; muscle strength.

\section{RESUMO}

Introdução: Um dos principais problemas enfrentados pelos treinadores de força e condicionamento físico é como quantificar e monitorar objetivamente a carga real de treinamento realizada pelos atletas para maximizar o desempenho. Sabe-se que o desempenho de atividades esportivas explosivas é grandemente determinado pela potência mecânica. Objetivo: Este estudo analisou a altura em que a potência de saída máxima é gerada e a carga correspondente em que é atingida em um grupo de esportistas do sexo masculino que praticam atletismo no teste de salto com contramovimento (SCM) com cargas adicionais (SCM). Métodos: Cinquenta atletas de nível nacional de corrida de velocidade e salto realizaram o teste $S C M$ com cargas crescentes até a altura de $16 \mathrm{~cm}$. A carga relativa que maximizou a potência de saída $\left(P_{\max }\right)$ foi determinada usando uma plataforma de força e um codificador linear de sincronização e estimada por potência máxima, média e tempo de vôo no SCM. Resultados: A carga em que a potência de saída já não existia foi na altura de 19,9 2,35, com relação a 99,1 \pm 1\% da potência de saída máxima. A carga que maximiza a potência de saída em todos os casos foi aquela em que o atleta salta em altura de aproximadamente $20 \mathrm{~cm}$. Conclusão: Esses resultados salientam a importância de considerar a altura atingida no SCM com carga adicional, em vez de com potência, porque a potência máxima sempre é obtida com a mesma altura. Aconselhamos o uso preferencial da altura atingida no teste $S \mathrm{SM}_{C}$ uma vez que parece ser um indicador válido da potência neuromuscular real do indivíduo, fornecendo informação para treinadores e preparadores físicos ao avaliar o desempenho de nossos atletas e quantificar e monitorar as cargas do treinamento, medindo a altura do salto no exercício de $\mathrm{SCM}_{c}$.

Descritores: desempenho atlético; atletismo; força muscula.

\section{RESUMEN}

Introducción: Uno de los principales problemas que los preparadores físicos enfrentan es el hecho de cómo objetivamente cuantificar y monitorear la carga de entrenamiento real utilizada por los atletas con el fin de optimizar el rendimiento. Es bien conocido que el rendimiento en actividades deportivas de carácter explosivo está determinado en gran medida por la potencia mecánica. Objetivo: Este estudio analizó la altura en la que se genera la máxima potencia y la carga correspondiente con la que se consigue, en un grupo de deportistas de atletismo del sexo masculino entrenados en el test de salto con contramovimiento (SCM) con cargas progresivas (SCM). Métodos: Cincuenta atletas hombres velocistas y saltadores de nivel nacional realizaron el test de $S C M$, incrementando las cargas hasta la altura de $16 \mathrm{~cm}$. La carga relativa con la que se alcanzó la máxima potencia $\left(P_{\max }\right)$ se determinó utilizando una plataforma de fuerza sincronizada con un codificador lineal y estimando la potencia mediante la potencia pico, la potencia media y el tiempo de vuelo en el SCM. Resultados: La carga con la que la potencia máxima no más existía fue en la altura de 19,9 2,35, con referencia al 99,1 $1 \%$ de la potencia máxima. La carga con la que se alcanza la potencia máxima en todos los casos ha 
sido con aquella con la que el atleta salta una altura de aproximadamente $20 \mathrm{~cm}$. Conclusión: Estos resultados destacan la importancia de considerar la altura alcanzada en SCM con carga extra en lugar de la potencia, puesto que la potencia máxima siempre se alcanza a la misma altura. Es muy recomendable priorizar el empleo de la altura alcanzada en el test $\mathrm{SCM}_{c}$ ya que parece ser un indicador válido del potencial neuromuscular real de un individuo proporcionando una información válida para entrenadores y preparadores físicos para evaluar la condición de rendimiento de nuestros atletas y cuantificar y monitorear las cargas de entrenamiento, solamente midiendo la altura del salto en el ejercicio de SCM.

Descriptores: rendimiento atlético; atletismo; fuerza muscular.

\section{INTRODUCTION}

One of the main problems faced by strength and conditioning coaches is the issue of how to objectively quantify and monitor the actual training load undertaken by athletes in order to maximize performance?.

Traditionally, coaches have shown great interest in those tests that enable them to predict athletic performance, several studies have used vertical jump and squat exercise for predict performance in athletes ${ }^{2,3}$. Therefore, these tests have become an important aspect in assessing the physical abilities of athletes. In particular, it is well accepted that performance in vertical jump and squat are good predictors of muscle strength, and therefore are used as standard tests of athletic performance ${ }^{2-5}$.

It is well known that performance of explosive sports activities is largely determined by mechanical power ${ }^{6}$. Mechanical power can be defined as the rate at which force $(F)$ is developed over a range of motion (d), in a specific period of time (t) $[P=F \cdot d / t]$, or as force multiplied by velocity $(v)[P=F \cdot v]^{6,7}$, each of which is influenced by the intrinsic properties of muscle ${ }^{8,9}$, such as length-tension and speed-strength relationship. The power development and its effect on performance has always been studied by researchers of sports performance ${ }^{6}$.

The power is the product of force and velocity. The absolute velocity is slightly modified, and only explains significantly speed -and power- with which loads are executed when they are low or very low ${ }^{10}$. Moreover, the movement velocity at which a load is moved, is closely and positively related to the difference between applied force and the force that represents itself to overcome resistance ${ }^{11}$. Therefore, the most important determinant of power is applied force.

It is obvious that an increase in strength may lead to an increased power output. According to Stone et al. ${ }^{12}$ maximum strength is related to power production and that increases in maximum strength may lead to an increased in power production. One possible explanation may be due to the increase of maximum strength at a given absolute load that may represent a relative load (\% RM) lower, so that as the work of Gonzalez-Badillo et al. ${ }^{1}$ this lower percentage can be shifted at a higher speed, with a subsequent increase in power for this load.

The question of which is the load that generates the maximal power output $\left(P_{\text {max }}\right)$ has been the subject of much debate in the exercise sciences for many exercises. The question of which is the relative load (\%1RM) that produce the $P_{\max }$ has been one of the most controversial topic for researches. The percentages of $1 \mathrm{RM}$ with which the maximum power is achieved are not clear, and, according to different authors, it has been found considerable variability from 10 to $80 \%$ of $1 \mathrm{RM}$ in the relative loads that produce the $P_{\max ,}$ depending on the type of exercise performed and/or muscle groups involved, experience of subjects involved (novice vs. well-trained athletes) and the type of training performed ${ }^{11-14}$ and methodological measures of power type ${ }^{15}$.

Initially, it was reported that relatively light loads such as 30\% of maximum isometric force ${ }^{16}$ or maximum muscle shortening velocity ${ }^{17}$ maximized power output. However, more recent research conducted using multi-joint dynamic muscular actions in isoinertial conditions, has found considerable variability $(20-80 \% 1 \mathrm{RM})$ in the relative loads that produce the $P_{\max }{ }^{18-22}$.
There is still much research on the study on the production of maximum power and optimal load at which is achieved ${ }^{23}$. A greater understanding of these issues can provide valuable information for monitoring and dose of training.

To the best of our knowledge, there is no study that has undertaken a detailed examination of the load that generates the maximal power output $\left(P_{\max }\right)$ in $C M J$ and $C M J$ with external loads tests $\left(C M J_{E L}\right)$. Thus, the aim of this investigation was to determine the height at maximal power output is generated and the corresponding load with which is achieved in a group of trained male track and field athletes.

\section{METHODS}

The present study used a cross-sectional experimental design to examine the load that maximizes the mechanical power output in CMJ in a group of trained male track and field athletes. All testing was carried out during two competitive track and field seasons. Each athlete participated in national and international events during this period and had experience with resistance training. Consequently, all the athletes were highly trained and familiar with the testing exercise.

Fifty men national level athletes in sprinting and jumping volunteered to take part in this study. Data are expressed with mean \pm SD (age $25.4 \pm 4.5$ years, weight $75.5 \pm 7.3 \mathrm{~kg}$, height $179.9 \pm 5.6 \mathrm{~cm}$; body fat percentage $9.9 \pm 2.3 \%$ ), a total of two hundred tests of $\mathrm{CMJ}_{\mathrm{EL}}$ were performed. No physical limitations or musculoskeletal injuries that could affect testing were reported. All participants were informed in detail about the content of the study, its objectives, potential risks and benefits, and they all signed informed consent prior to participation. The study was approved by the Research Ethics Committee of Pablo de Olavide University.

Participants were familiar with the testing procedures because they had been performing the exercises as part of their normal training routine. After standardized warm-up, participants performed 3 maximal CMJ trials on a Smith machine while standing on a portable force platform (Isonet, JLML, Madrid, Spain).

The bar of the Smith machine had a linear transducer attached to it (Isocontrol, JLML, Madrid, Spain), which was synchronized with the force platform.

The force platform was connected to a portable computer and recorded data at a sample rate of $1.000 \mathrm{~Hz}$. The rotary encoder of the linear transducer recorded the position and direction of the bar to within an accuracy of 0,2 mm. Average power was calculated by the product of velocity taken with the linear transducer and the ground reaction force measured by the portable force platform.

Participants stood on the Smith machine and rested the bar $(17 \mathrm{~kg})$ on their shoulders. Participants initiated the CMJ from a standing position and performed a crouching action followed immediately by a jump for maximal height. Hands remained holding on to the bar for the entire movement to maintain contact between the bar and shoulders. Three minutes of rest were provided between each trial to minimize the likelihood of fatigue.

Height was measured to the nearest $0.5 \mathrm{~cm}$ during a maximal inhalation using a wall-mounted stadiometer (Seca 202, Seca Ltd., Hamburg, Germany). Body weight and fat percentage were determined using 
an 8-contact electrode segmental body composition analyzer (Tanita BC-418, Tanita Corp., Tokyo, Japan).

All 50 subjects performed $\mathrm{CMJ}_{\mathrm{EL}}$ test with increasing loads until jump height was less than $16 \mathrm{~cm}$. All subjects performed the tests in the same conditions, so in this case there were no situational variables. The tests were performed during a session for each of the groups. Each group had a maximum of 6 subjects with the objective of the recovery time were 3 minutes. The total duration of the test was scheduled for two hours. The measurement was carried to a group per day, given that the time slot, from 18:00 to 20:00, was the same for each group. Countermovement Jump. A CMJ was used in order to maximize stretchshortening cycle activity and to assess explosive strength of the lower extremity muscles. The CMJ test was performed using an infrared timing system (Optojump, Microgate, Bolzano, Italy). During the CMJ, the subject was instructed to rest his hands on his hips while performing a downward movement followed by a maximal effort vertical jump. All subjects were instructed to land in an upright position and to bend the knees following landing. Five jumps were made, separated by approximately one minute of rest. Removed the two extreme values (the best and the worst) and the average was calculated with the other three jumps. and the average value was used for the subsequent statistical analysis.

Countermovement Jump with External Load $\left(\mathrm{CMJ}_{\mathrm{EL}}\right)$. CMJ test was followed by a CMJ with extra load test. The test was performed in a Smith machine (Multipower Fitness Line, Peroga, Spain) that allows a smooth vertical displacement of the bar along a fixed pathway was used for all tests. Two warm-up jumps were made with the first load test; the subjects rested two minutes and after started the test. A progressive loading test was made, each of the established loads was set with the Smith machine. The test began with a load of 17-kg, and the weight was increased in 10-kg increments. The test ended when the subject jumped a height of less than $16 \mathrm{~cm}$. This height was used because jumps lower than that progressively decrease the reliability of the jump and it decreases the risk of injury.

\section{Statistical Analyses}

Standard statistical methods were used for the calculation of means and standard deviations (SD). Intraclass correlation coefficient (ICC) was used to determine between-subject reliability of jumping tests. T-Tes paired was used to detect differences between loads. Relationship between relative load and power output was studied by fitting second-order polynomials to data. Significance was accepted at the $P<0.05$ level.

\section{RESULTS}

In this study CMJ showed good reliability: Intraclass Correlation Coefficient (ICC) of 0.97, Confidence Interval (95\% Cl: 0.93 to 0.98) and Coefficient of Variation (CV) of 2.5\% (Table 1).

Shows the height with each load and the normalized $P_{\max }$ (\% of maximum) according to calculations made using the second-order polynomial curve fitted to individual load-power data points shown in Figure 1. For this, 1.804 raw data derived from the 200 incremental tests performed in $\mathrm{CMJ}_{L}$ test were used. After plotting power for each load and fitting a second-order polynomial to all data points, a close fit $\left(R^{2}=0.9713\right)$ was observed (Figure 1).

The load that maximized the mechanical power output was found to be the load at which each athlete can jump approximately $20 \mathrm{~cm}$ and this (load for $20 \mathrm{~cm}$ ) represents as mean the body weight of subjects. In order to calculate the $P_{\max }$ load, a second-order polynomial curve was fitted to individual load-power data points. The power data were expressed relative to the maximum power output value obtained in each load for each test performed (200 incremental tests). Power output was maximized at a load which athlete can jump approximately $20 \mathrm{~cm}$ (Table 1 and Figure 1). Statistically significant differences in power output (\% of maximum) were found for different loads between 17-kg and 87-kg (Table 1). These values were obtained from the respective individual second-order polynomial fits to each subject's raw data, which gave $R^{2}$ values of $0.9713 \pm 0.02$

Table 1. Values of Height and $P_{\max }$ for each load in the CMJ with extra loads test.

\begin{tabular}{c|c|c}
\hline Load (kg) & Height (cm) & Power (\% of maximun) \\
\hline 0 & $48,81 \pm 4,75$ & $86,11 \pm 5,20$ \\
\hline 17 & $31,3 \pm 3,87$ & $87,1 \pm 4,77$ \\
\hline 27 & $27,2 \pm 3,32$ & $92,3 \pm 4,77$ \\
\hline 37 & $25,6 \pm 4,12$ & $94,1 \pm 3,84$ \\
\hline 47 & $22,6 \pm 3,03$ & $96,5 \pm 3,49$ \\
\hline 57 & $21 \pm 3,44$ & $97,7 \pm 2,52$ \\
\hline 67 & $20,1 \pm 2,93$ & $97,5 \pm 1,63^{* *}$ \\
\hline 77 & $19,9 \pm 2,35$ & $99,1 \pm 1$ \\
\hline 87 & $17,5 \pm 2,23$ & $97,4 \pm 1,89^{* *}$ \\
\hline 97 & $16,9 \pm 0,91$ & $97 \pm 2,3$ \\
\hline
\end{tabular}

The asterisks indicate significant differences between the Pmax (load for $77-\mathrm{kg}$ ) and the previous and the nex loads (load for $67-\mathrm{kg}$ and $87-\mathrm{kg}$ ); ${ }^{* *}: \mathrm{p}<0.01$

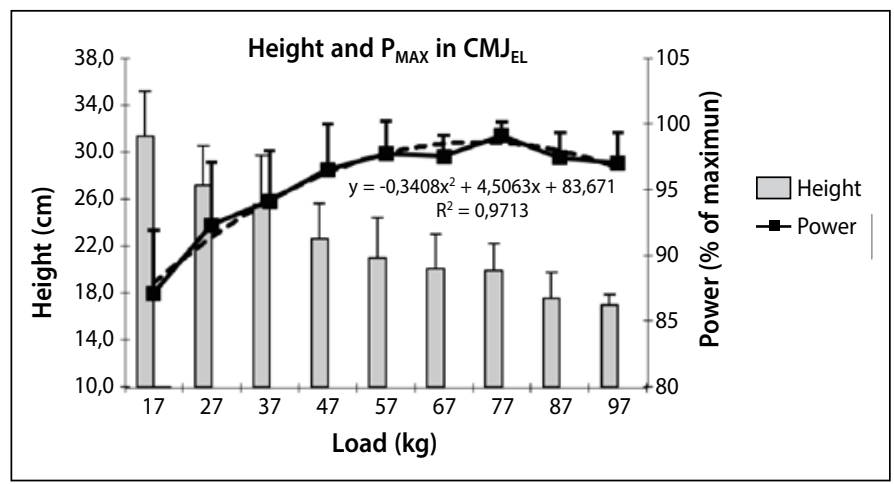

Figure 1. Height and Pmax for each load in the CMJ with extra loads test.

\section{DISCUSSION}

The results of this study highlight the importance of considering the relative power and its corresponding height in $\mathrm{CMJ}$ with extra loads test when assessing the physical state and athletic performance of elite track and field athletes. The main finding of this investigation was that the maximum power load when assessing athletic performance in elite athletes in $\mathrm{CMJ}_{\mathrm{EL}}$ test was achieved with a load with which an athlete jump a height of approximately $20-\mathrm{cm}$, independently of absolute value in power output. Surprisingly, to the best of our knowledge, this is something that no previous research had noticed. The present study also adds to previous research by corroborating that, independently the procedures for measuring power, referring these procedures by force platform, force platform and lineal encoder synchronization and estimating the power by the flight time in CMJ, the load that maximizes power output in all cases has been with which load than an athlete jump a height of approximately $20 \mathrm{~cm}$, and this provides evidence that there is a clearly defined point in the load spectrum that maximizes power output in $\mathrm{CMJ}_{\mathrm{EL}}$ test approximately from $19 \mathrm{~cm}$ to $21 \mathrm{~cm}$.

To our knowledge, this is first study to do this type of analysis, ie, there is much literature that analyzes the maximum power load as a \% of the RM in the squat ${ }^{13,18}$ but none has done an analysis which studies the loads that can achieve a height at which maximum power is attained.

The mechanical power is dependent on the external load ${ }^{24}$. The optimum relative load at which maximum power is developed, expressed as a percentage of one repetition maximum (1RM) is different for each exercise ${ }^{25}$. Focusing on the exercise of $\mathrm{CMJ}_{\mathrm{EL}}$, Baker et al..$^{13}$ observed the load at which maximum power was achieved was 30-40\% for men and 30-50\% RM for women in the exercise of $\mathrm{CMJ}_{\mathrm{EL}}$. Cormie et al. ${ }^{18}$ collected the maximum mechanical power during a squat jump was obtained with the body weight of the subject itself, which is about 30\% of the maximum dynamic strength from it. Several studies found that the load at which maximum power is attained in the $\mathrm{CMJ}_{\mathrm{EL}}$ was unloaded ${ }^{25,26}$. 
The problem is the procedure for assessment, ie Cormie et al. ${ }^{18}$ measured the peak power and in our study we measured average power, so it becomes more difficult to make comparisons between studies.

By contrast, Stone et al. ${ }^{12}$ recorded that the optimum load to achieve maximum power in squat jump and $\mathrm{CMJ}_{\mathrm{EL}}$ was $10 \% \mathrm{RM}$, but keep in mind that in this work the lowest charge made was this. Another study by Harris et al. ${ }^{26}$ found that the maximum power for both the peak power (PP) and for average power $\left(P_{\text {avg }}\right)$ was attained with loads of $21.6 \pm 7.1 \%$ and $39.0 \pm 8.6 \%$ of the RM in the squat, respectively. So this may explain in part the lack of unanimity in the results with the literature, since almost all the work load measured with the PP is reached, while we analyze the load is reached the $P_{\text {avg }}$.

Another consideration is the methodology used to determine the mechanical power. It has been shown recently ${ }^{18,23}$ that to use 2 linear transducers and a force platform is the optimal method for measuring the PP, because the kinematic data without the strike (eg Without the force platform) often underestimates the PP observed in the literature ${ }^{13}$, and thus is difficult to determine the optimal load if you rely on PP.

In summary, the findings of the present study show the importance of referring the height achieved in CMJ with extra load instead of power because the maximum power always is attained with the same height. We advocate for the preferential use of height achieved in the $\mathrm{CMJ}_{\mathrm{EL}}$ test since it seems to be a better indicative of an individual's actual neuromuscular potential. Improvement in jumping ability is a major training goal for many sports, and CMJ is a well-recognized training exercise used to achieve this. In individual sports such as track and field, athletes must improve jump performance to achieve better personal best records.

These findings have important practical applications for the prescription and monitoring of training load in resistance training, making it possible to: For coaches and trainers, monitoring of the vertical jump height under various load conditions can be used as a specific evaluation of the features observed in sport that maximum power is reached to the load with which it reaches a height of about $20 \mathrm{~cm}$ in CMJc and facilitates control and scheduling of training loads.
The load which an athlete can jump a height of approximately $20 \mathrm{~cm}$ in CMJ with a external load is the load permitted the most favourable combination of force and velocity values, which, in turn, yielded the maximal mechanical power output, regardless of the absolute load used. This is the first study to analyze the height at which maximum power is reached in the exercise of $\mathrm{CMJ}_{\mathrm{EL},}$ providing a valid information from coaches and trainers when assessing the status of performance of our athletes and to quantify and monitoring training loads, only measuring the height of the jump in the exercise of $\mathrm{CMJ}_{\mathrm{EL}}$. Coaches often express the need to have access to an easily administered test that will allow assessment of the athlete without actually measuring the sport performance. This study, for the ease of the test, represents one approach to assessing the physical state of elite track and field athletes that might satisfy this need. The present study is expected to contribute to the field of exercise science by allowing a more rational characterization and monitoring of the resistance training stimulus for track and field athletes.

\section{CONCLUSIONS}

These results highlight the importance of considering the height achieved in CMJ with extra load instead of power because the maximum power always is attained with the same height. We advise for the preferential use of height achieved in the $\mathrm{CMJ}_{\mathrm{EL}}$ test since it seems to be a valid indicative of an individual's actual neuromuscular potential providing a valid information from coaches and trainers when assessing the status of performance of our athletes and to quantify and monitoring training loads, only measuring the height of the jump in the exercise of $\mathrm{CMJ}_{\mathrm{EL}}$.

\section{ACKNOWLEDGMENTS}

The authors thank all the athletes who participated as subjects in this study. No sources of funding were used in the preparation of this article.

All authors have declared there is not any potential conflict of interests concerning this article.

CONTRIBUIÇÕES DOS AUTORES: Each one of the authors has contributed significantly to the proccess of the study and the development of the manuscript unti the final version. PJR (0000-0002-8156-243X)*, VCP (0000-0001-7581-2706)*, FPB (0000-0001-9114-0348)* and JJGB (0000-0002-3669-365X)* were the main contributors in the writing of the manuscript. PJR, VCP, FPB, JPM (0000-0002-0250-0717)*, FJTB (0000-0002-3977-1844)* and JJGB worked actively in the data collection for this manuscript. PJR, VCP, FPB, JPM, FJTB and JJGB participated significantly in the discussion section and approved the final version of this manuscript. * ORCID Number (Open Researcher and Contributor ID).

\section{REFERENCES}

1. González-Badillo JJ, Sánchez-Medina L. Movement velocity as a measure of loading intensity in resistance training. Int J Sports Med. 2010;31(5):347-52.

2. López-Segovia M, Palao Andrés JM, González-Badillo JJ. Effect of 4 months of training on aerobic power, strength, and acceleration in two under-19 soccer teams. J Strength Cond Res. 2010;24(10):2705-14.

3. Gorostiaga EM, Izquierdo M, Ruesta M, lribarren J, González-Badillo JJ, Ibáñez J. Strength training effects on physical performance and serum hormones in young soccer players. Eur J Appl Physiol. 2004;91 (5-6):698-707.

4. Bosco C, Luhtanen P, Komi PV. A simple method for measurement of mechanical power in jumping. Eur J Appl Physiol Occup Physiol. 1983;50(2):273-82.

5. Driss $\mathrm{T}$, Vandewalle $\mathrm{H}$, Monod $\mathrm{H}$. Maximal power and force-velocity relationships during cycling and cranking exercises in volleyball players. Correlation with the vertical jump test. J Sports Med Phys Fitness. 1998;38(4):286-93.

6. Cronin J, Sleivert G. Challenges in understanding the influence of maximal power training on improving athletic performance. Sports Med. 2005;35(3):213-34.

7. Tillin NA, Bishop D. Factors modulating post-activation potentiation and its effect on performance of subsequent explosive activities. Sports Med. 2009;39(2):147-66

8. Schmidtbleicher D. Training for power events. In: Komi PV. Strength and power in sport. London: Blackwell Scientific Publications; 1992. p. 381-395.

9. Moritani T. Motor unit and motoneurona excitability during explosive movement. In: Komi PV. Strength and power in sport. London: Blackwell Science; 2003. p. 27-49.

10. Verkhoshansky Y. Fundamentals of special strength training in sport. Livonia: Michigan Sportivny Press; 1986.

11. González-Badillo JJ. Bases teóricas y experimentales para la aplicación del entrenamiento de fuerza al entrenamiento deportivo. Infocoes. 2000;5(2):3-14.

12. Stone MH, O'Bryant HS, McCoy L, Coglianese R, Lehmkuhl M, Schilling B. Power and maximum strength relationships during performance of dynamic and static weighted jumps. J Strength Cond Res. 2003;17(1):140-7.

13. Baker D, Nance S, Moore M. The load that maximizes the average mechanical power output during jump squats in power-trained athletes. J Strength Cond Res. 2001;15(1):92-7.

14. Behm DG, Sale DG. Intended rather than actual movement velocity determines velocity-specific training response. J Appl Physiol (1985). 1993;74(1):359-68
15. Sanchez-Medina L, Perez CE, Gonzalez-Badillo JJ. Importance of the propulsive phase in strength assessment. Int J Sports Med. 2010;31(2):123-9.

16. Kaneko M, Fuchimoto T, Toji H, Suei K. Training effect of different loads on the force-velocity relationship and mechanical power output in human muscle. Scand J Sports Sci. 1983;5:50-5.

17. Edgerton VR, Roy RR, Gregor RJ, Rugg S. Morphological basis of skeletalmuscle power output. In: Jones NL, McCartney N, McComas, AJ (editors). Human muscle power. Champain, IL: Human Kinetics; 1986

18. Cormie P, McCaulley GO, Triplett NT, McBride JM. Optimal loading for maximal power output during lower-body resistance exercises. Med Sci Sports Exerc. 2007;39(2):340-9.

19. Izquierdo M, Häkkinen K, Gonzalez-Badillo JJ, Ibáñez J, Gorostiaga EM. Effects of long-term training specificity on maximal strength and power of the upper and lower extremities in athletes from different sports. Eur J Appl Physiol. 2002;87(3):264-71.

20. Cormie P, McBride JM, McCaulley GO. The influence of body mass on calculation of power during lower-body resistance exercises. J Strength Cond Res. 2007;21(4):1042-9.

21. Izquierdo M, Ibañez J, Gorostiaga E, Garrues M, Zúñiga A, Antón A, et al. Maximal strength and power characteristics in isometric and dynamic actions of the upper and lower extremities in middle-aged and older men. Acta Physiol Scand. 1999;167(1):57-68.

22. Siegel JA, Gilders RM, Staron RS, Hagerman FC. Human muscle power output during upper- and lower-body exercises. J Strength Cond Res. 2002;16(2):173-8.

23. Dugan EL, Doyle TL, Humphries B, Hasson CJ, Newton RU. Determining the optimal load for jump squats: a review of methods and calculations. J Strength Cond Res. 2004;18(3):668-74.

24. Zatsiorsky VM, Kraemer WJ. Science and practice of strength training. Champaign, LL: Human Kinetics; 2006.

25. Jandacka D, Vaverka F. A regression model to determine load for maximum power output. Sports Biomech. 2008;7(3):361-71.

26. Harris NK, Cronin JB, Hopkins WG. Power outputs of a machine squat-jump across a spectrum of loads. J Strength Cond Res. 2007;21(4):1260-4

27. Kraska JM, Ramsey MW, Haff GG, Fethke N, Sands WA, Stone ME, et al. Relationship between strength characteristics and unweighted and weighted vertical jump height. Int J Sports Physiol Perform. 2009;4(4):461-73 